\title{
STRENGTHENING INDONESIA NAVAL BASE AS A AIRCRAFT CARRIER AT THE FRONTIER TO INCREASE POWER OF DETERRENCE AND STATE DEFENSE AT SEA
}

\author{
Zulkifli Muhammad ${ }^{\star}$, Moeljadi, Fadli M., Nurjanah \\ Postgraduate Program, University of Brawijaya, Malang, East Java, Indonesia \\ ${ }^{\star}$ E-mail: zulkifli@student.ub.ac.id
}

\begin{abstract}
Indonesia is located in a very strategic position between the continents of Asia and the continent of Australia and the Pacific Ocean and the Indian Ocean, which makes Indonesia a sea line of communication (SLOC) and sea trade route (Sea Lines of Trade / SLOT) for the international world. The size of the Indonesian Navy (TNI AL) territory carried out with the potential threats faced is still not comparable. In order to secure the border areas and maintain the country's sovereignty, President Joko Widodo intends to build the islands of Natuna, Bitung, and Selaru as Aircraft carriers. The Navy can support this desire by strengthening the Naval Bases located in the three regions. Strengthening the Naval Base can be done by analyzing the essential functions and duties of the base and the general requirements of the base. Furthermore, an analysis of the capabilities and technology of weapons owned by the Aircraft carriers of countries in the world can be used as a reference for constructing Indonesian Aircraft carriers. In addition, an analysis of the Naval Base from the Naval Base and Naval Home Base levels is the most appropriate for strengthening to increase the country's deterrence and defense at sea. From the analysis results, three selected Naval bases were determined, namely: Naval Base Ranai, Naval Home Base VIII Manado, and Naval Base Saumlaki.
\end{abstract}

\section{KEY WORDS}

Indonesia naval base, aircraft carriers, power of deterrence.

Geographically, Indonesia is located in a very strategic position, namely the crossworld position, which is located between two continents (Asia and Australia) and two oceans (the Pacific Ocean and the Indian Ocean). This position makes Indonesia a sea line of communication (SLOC) and sea line of trade (SLOT) for the international community (Geoffrey, 2009). This is very beneficial for Indonesia to establish good relations with countries on the two continents. In the territory of Indonesia, there are several strategic straits, which are the routes of the world economy. The straits are the Malacca Strait, the Singapore Strait, the Sunda Strait, the Lombok Strait, the Makassar Strait, and the OmbaiWetar Strait (Kurnia, 2017). In addition to providing benefits to Indonesia, this strategic position can also threaten state sovereignty, such as territorial violations, theft of marine resources, smuggling of goods, smuggling of narcotics and dangerous drugs, human smuggling, hijacking, piracy, wiretapping, and sabotage by state actors and non-state actors who have specific goals for the benefit of their group (Zulkifli, 2021). In terms of its area, Indonesia is the largest archipelagic country in the world and has 17,504 islands, of which 16,056 islands have received recognition from the United Nations (Prasetya, 2021). In addition, Indonesia is the $7^{\text {th }}$ largest country in the world after Russia, Canada, the United States, China, Brazil, and Australia. When compared with countries in Asia, Indonesia is ranked $2^{\text {nd }}$, and in Southeast Asia, Indonesia is the largest country (Putra, 2016).

Apart from Indonesia, several other countries in this region are neighboring countries, so that Indonesia has maritime and land borders with several nations. In terms of naval boundaries, Indonesia is bordered by ten neighboring countries. The borders in the western region are with Malaysia, Singapore, Thailand, Vietnam, the Philippines, and India. At the same time, the borders in the eastern region are with Timor Leste, Palau, Papua New Guinea, and Australia. Meanwhile, the mainland borders three neighboring countries, namely 
the border with Malaysia in West Kalimantan, East Kalimantan, North Kalimantan, Timor Leste in East Nusa Tenggara, and Papua New Guinea in Papua (Ritonga, 2016).

Prior to the Djuanda Declaration, the territory of Indonesia still referred to the 1939 Dutch East Indies Ordinance, namely Teritoriale Zeeen en Maritieme Kringen Ordonantie 1939 (TZMKO 1939). In this regulation, the islands in the archipelago are separated by the surrounding sea, and each island only has a sea boundary of 3 miles from the coastline. This means that foreign ships may unobstructedly sail the sea that separates the islands in the archipelago. The Djuanda Declaration became the forerunner of forming the primary legal effort for Indonesia as an archipelagic country. In the Djuanda Declaration, Indonesia adheres to the principle of an archipelagic state so that the seas between islands are also part of the territory of Indonesia and are not accessible areas. The Djuanda Declaration was inaugurated into UU No. 4/PRP/1960 concerning Indonesian waters so that the area of Indonesia is two and a half times larger than before, from 2,027,087 $\mathrm{km}^{2}$ to $5,193,250 \mathrm{~km}^{2}$ (Kurnia, 2017). The world only recognized international recognition through The United Nations Convention on The Law of the Sea 1982 (UNCLOS 1982). Furthermore, Indonesia ratified UU No. 17 of 1985. Based on UNCLOS 1982, the sea became an integral part of the territory of Indonesia which cannot be separated but can be distinguished according to the legal regime that governs it. This is intended so that other countries also still have the right to use the sea as regulated in UNCLOS 1982 (Ibid).

The Indonesian Archipelagic Sea Lane (IASL) is a sea lane traversed by countries that carry out a peaceful passage. IASL is a channel for shipping and aviation that can be used by foreign ships or aircraft to carry out voyages or flights under international maritime law. IASL is established to carry out international shipping and flights directly and is not hindered by Indonesian territorial waters and airspace. With IASL, it can connect two open waters, the Indian Ocean and the Pacific Ocean. Indonesian waters have a significant and strategic role as world shipping lanes. This region will become increasingly important in the future, in line with the increasing demand for energy and other natural resources, which are expected to increase by $56 \%$ by 2040 (Supandi, 2015). Indonesian territorial waters, especially in the Malacca Strait, are considered a critical route for world trade other than the Hormuz Strait, Suez Canal, and Panama Canal (lbid).

In order to face the development of this strategic environment, the Indonesian Navy must always be ready to guard, protect and secure and enforce sovereignty in Indonesia's marine territory. This task of the Indonesia Navy has been mandated in UU No. 34 of 2004 concerning the Indonesian National Armed Forces, in Article 9, it is stated that the Navy is in charge of (Republic of Indonesia, 2004):

a. Carry out the duties of the Indonesian National Armed Forces in the field of defense.

b. Enforce the law and maintain security in the marine area of national jurisdiction under the provisions of national law and ratified international law.

c. Carry out naval diplomacy duties in order to support foreign policy policies set by the government.

d. Carry out the duties of the Indonesian National Armed Forces in the development and strength development of the marine dimension.

e. Implement the empowerment of the marine defense area.

However, to carry out the mandate of the Law, compared to the area of the Navy's field of work with the potential threats that must be faced, the current strength refers to the Minimum Essential Force (MEF) standard still needs to be improved (Zulkifli, 2021). Therefore, President Joko Widodo, as the Supreme Commander of the Indonesian National Armed Forces (TNI), when watching the XXXIV Fleet Jaya Exercise in 2016, said that the Indonesian National Armed Forces would soon have three new aircraft carriers. However, this aircraft carrier is not an actual aircraft carrier, but by turning the three outer islands of Indonesia into military bases to protect the sovereignty of the Unitary States of the Republic of Indonesia. The President plans that this aircraft carrier will be built on the three outermost islands, namely: Natuna, Bitung, and Selaru (Https://Katadata.Co.ld , 2021).

Based on the preceding passage, in this article, the problem discussed is about strengthening the Naval Base as a aircraft carrier at the frontier to increase power of 
deterrence and national defense at sea. In strengthening the base, a qualitative descriptive analysis method was used. This method is used to analyze, provide an overview, and summarize various conditions and situations from the data collected, both from the results of interviews and observations, regarding the problems studied and occurring in the field (Wiratha, 2006). In comparison, the problem formulation is how to strengthen the Indonesian Naval Base as a aircraft carrier at the frontier to increase the power of deterrence and national defense at sea.

\section{METHODS OF RESEARCH}

The strength of the Indonesian Navy is influenced by several components, such as the power structure, technological sophistication, readiness, and operational sustainability of the primary weapon system owned (Zulkifli, 2019). Based on the focus and purpose of this article, the method used is a qualitative-descriptive-analytical method that produces strategic concepts in the context of strengthening the Indonesian Naval Base. This method is used to determine the strengthening of the Indonesian Naval Base as a aircraft carrier at the frontier to increase power of deterrence and national defense at sea.

The Chief of Naval Staff has issued a decree numbered: Kep/1771/XI/2013 concerning the Manual of Standardization Administration for Indonesian Naval Bases. In this decree, it is explained that the Naval Base has the main functions and duties as well as the following general requirements (Mabesal, 2013).

The Indonesian Naval Base carries out the following functions:

- Operational unit support function which includes anchoring facility, support function, maintenance and repair facility, logistic support function, debriefing facility support function, personnel maintenance facility support function and base coaching facility support function;

- Marine Security Function;

- The function of National Potential Development to become a defense force in the maritime sector;

- Maritime Territorial Development Function.

The main duty of the Naval Base is to provide administrative and logistical support for elements of the Navy, namely: ships, aircraft, Marines, and carry out potential maritime development by utilizing the facilities and infrastructure owned by the base itself and related facilities and infrastructure. In addition to the main tasks, the Naval Base also has an additional task, namely providing support for non-Navy units according to their functions and needs.

In order to support the implementation of the main duties mentioned above, the Naval Base must meet the general requirements as follows:

- Environmental conditions where the base is located, which includes geographical and resource conditions. Geographical conditions, particularly the position of the base to the shipping lane is good; have good land, waters, and space to facilitate the movement and activities of elements of the Integrated Fleet Weapon System (IFWS); close to freshwater sources, as well as other environmental facilities that support the essential tasks of the base. Meanwhile, the condition of resources is the level of the economic capacity of the area where the base is located, which includes: available sources of raw materials and basic material needs; available support for industrial facilities, especially the maritime industry in the form of industrial material needs, maintenance services, transportation services, and so on;

- In accordance with its function as a supporter, the base must: be able to ensure the dispersion of ships, aircraft, and marine troops to carry out their operational tasks; can ensure the operational readiness of each IFWS component on an ongoing basis; can create a favorable situation for ships, aircraft or marine troops themselves or friends, and otherwise complicate the movements of the opponent; have good defense and protection; have facilities following the operational requirements of the base. 
Aircraft carrier is a large warship specialized in the sea or ocean on which to operate aircraft (Dpdiknas, 2008). Admiral A.T. Mahan argues that whoever controls the oceans can rule the world. This is shown by European countries, especially Britain, which has a political policy to encourage its naval power to carry out ocean exploration. At that time, the strength of the British Navy was inseparable from the support of the rapid progress of science and technology due to the industrial revolution (Marsetio, 2013). This also affects other major countries, so that many big and developed countries are trying to have aircraft carriers. In this day and age, aircraft carriers are large ships created for war and have become a symbol of prestige and strength for countries' navies around the world.

Aircraft carriers have become one of the greatest assets for developed countries. From the beginning, aircraft carriers were created to make a big difference in the country's defense system. Aircraft carriers, also known as floating air bases, are equipped with complete flight deck facilities capable of carrying, arming, deploying, and recovering aircraft. The aircraft carrier can transport a lot of warplanes, helicopters, and other combat equipment.

In order to strengthen the Indonesian Naval Base so that it can function as a Aircraft carrier at the frontier to increase the country's power of deterrence and defense at sea, it is necessary to have knowledge of the existing aircraft carriers owned by major countries in the world. This aims to determine the capabilities of each aircraft carrier, including the weapons technology it possesses. So that it can be a reference for strengthening the Indonesian Naval Base, which will be used as a aircraft carrier. However, this article does not review the equipment systems related to ship maneuvering. This is because the system has nothing to do with aircraft carriers that are built by utilizing islands that permanent. The data about aircraft carriers in this article, quoted from the book Jane's Fighting Ships 2019-2020, are Pape, 2020):

a. Queen Alizabeth Class. The Queen Alizabeth Class aircraft carrier is owned by the United Kingdom (UK). The UK has two Aircraft carriers, namely Queen Elizabeth R08, launched on 17 July 2014, and Prince of Wales R09, which was launched on 21 December 2017. This Aircraft carrier has a flight deck for takeoff and landing with a length of 908.8 meters and 239.5 meters wide. The Aircraft carrier can carry around 40 aircraft consisting of 24 F-35B aircraft and 14 Merlin Mk2 helicopters and a combination of Merlin Mk2 or Mk4 helicopters, Wildcat, Chinook, and Apache. In addition, the Aircraft carrier is capable of accommodating 679 personnel (600 air groups) plus 95 flagstaffs and 250 troops.

The types of weapons owned by this Aircraft carrier are 3 Raytheon Mk 15 Phalanx Block 1B $20 \mathrm{~mm}$ cannons, Torpedo Defense Ultra Electronics Type 2170. It also has Thales 1046 (S1850M) Air Search Radar, BAE Air Search Radar, Surface Insyte type 997 (ARTISAN), Combat Data System BAE CMS-1, Link 16, and Electro-Optic System 2 Ultra Electronics Series 2500 EOS.

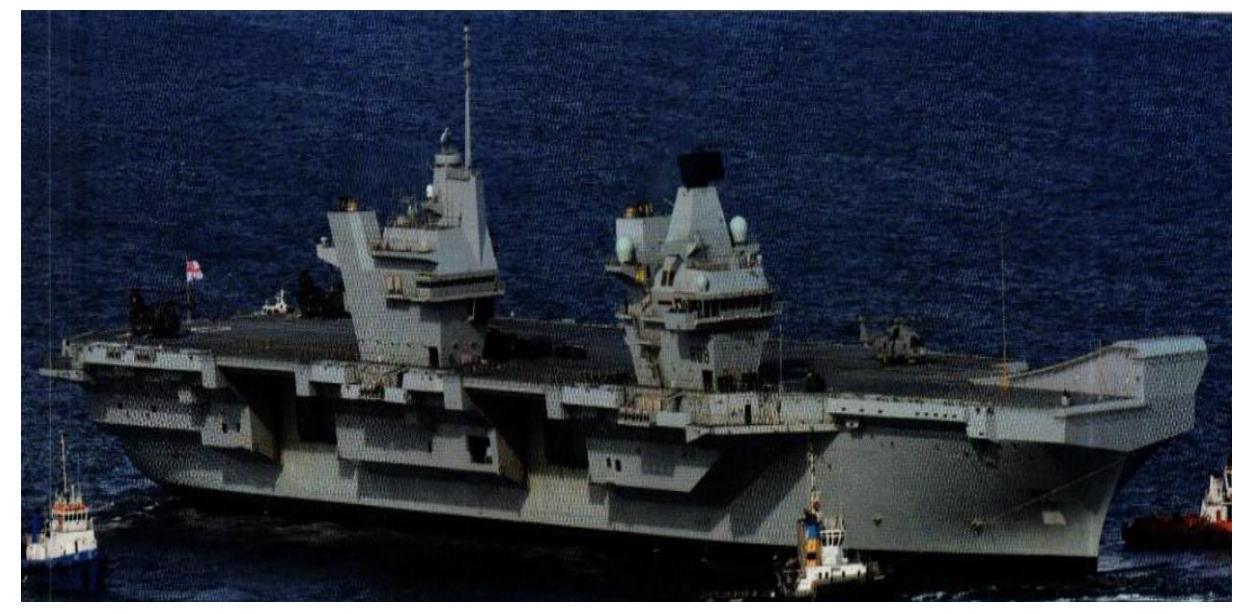

Figure 1 - Queen Elizabeth R08 (Source: Jane's Fighting Ships 2019-2020) 
b. Gerald $R$ Ford Class. The Gerald R Ford Class Aircraft carrier is owned by the United States of America (USA). America has a large number of Aircraft carriers, Gerald $R$ Ford CVN78, which was launched on November 17, 2013, and John F Kennedy CVN79 launched in 2020. This Aircraft carrier has a flight deck for takeoff and landing with a length of 1,091.9 meters and a width of 255,9 meters. The Aircraft carrier can carry more than 75 aircraft (F-35C, F/A-18E/F, EA-18G, E-2D, MH-60R/S) and MH-60R/S helicopters. In addition, this Aircraft carrier is also capable of accommodating 4,550 personnel.

The types of weapons owned by this Aircraft carrier are 2 Raytheon GMLS Mk 29 SAM Missiles, 3 Raytheon 20 mm Phalanx Block 1B Mk 15 6-barrelled cannon, Decoy SLQ-25C. Electronic Countermeasures ESM/ECM SEWIP Block 2/3. It is also equipped with Radar Air Search CVN 78. Combat Data System CEC, USG-2B, Link 4, 11, 16. Weapon Control System SSDS Mk II.

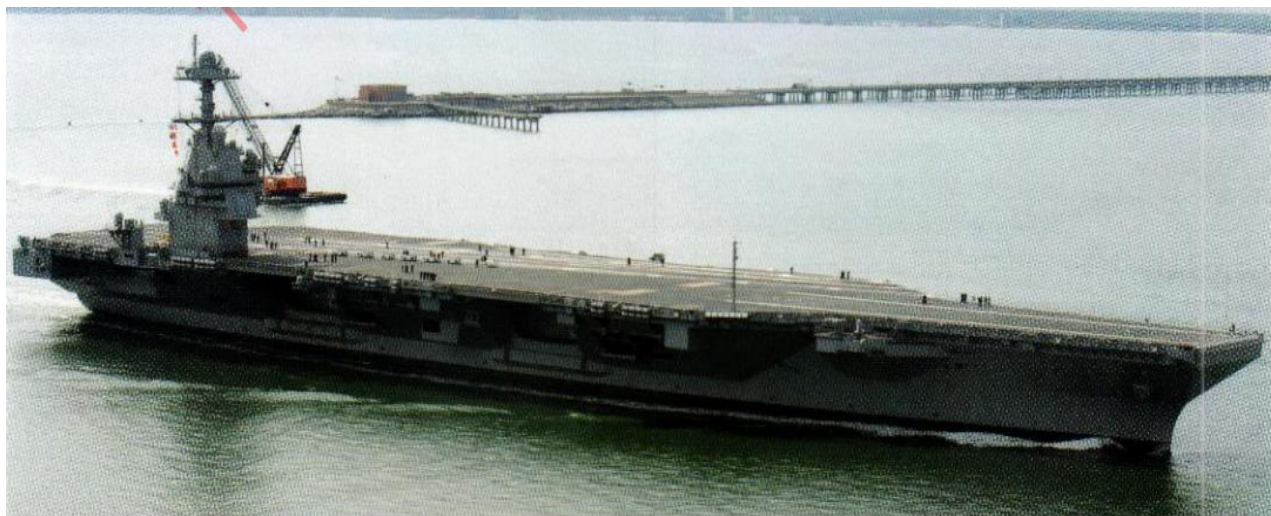

Figure 2 - Gerald R Ford CVN78 (Source: Jane's Fighting Ships 2019-2020)

In addition to the two Aircraft carriers, America still has ten Nimitz-class Aircraft carriers, namely: Nimitz CVN68, Dwight D Eisenhower CVN69, Carl Vinson CVN70, Theodore Roosevelt CVN71, Abraham Lincoln CVN72, George Washington CVN73, John C Stennis CVN74, Harry S Struman CVN75, Ronald Reagan CVN76, and George HW Bush CVN77. Currently, America is building a new Aircraft carrier with the name Enterprise CVN80, which is expected to be completed and launched in 2025.

c. Charles De Gaulle Class. The French State owns the Charles De Gaulle Class Aircraft carrier. The Aircraft carrier Charles De Gaulle R91 was launched on 7 May 1994. This Aircraft carrier has a flight deck for takeoff and landing with a length of 857.9 meters and a width of 211.3 meters. The Aircraft carrier can carry 2 E-2C Hawkeye, 24 Rafale F2, and F3 aircraft, 2 AS565 Panther or 2 AS332 Cougar (AF) helicopters, or 2 Puma/Super Puma plus 2 Dauphin SAR. In addition, this Aircraft carrier has the capacity to accommodate 1,890 personnel (600 aircrews) plus 90 flagstaffs.

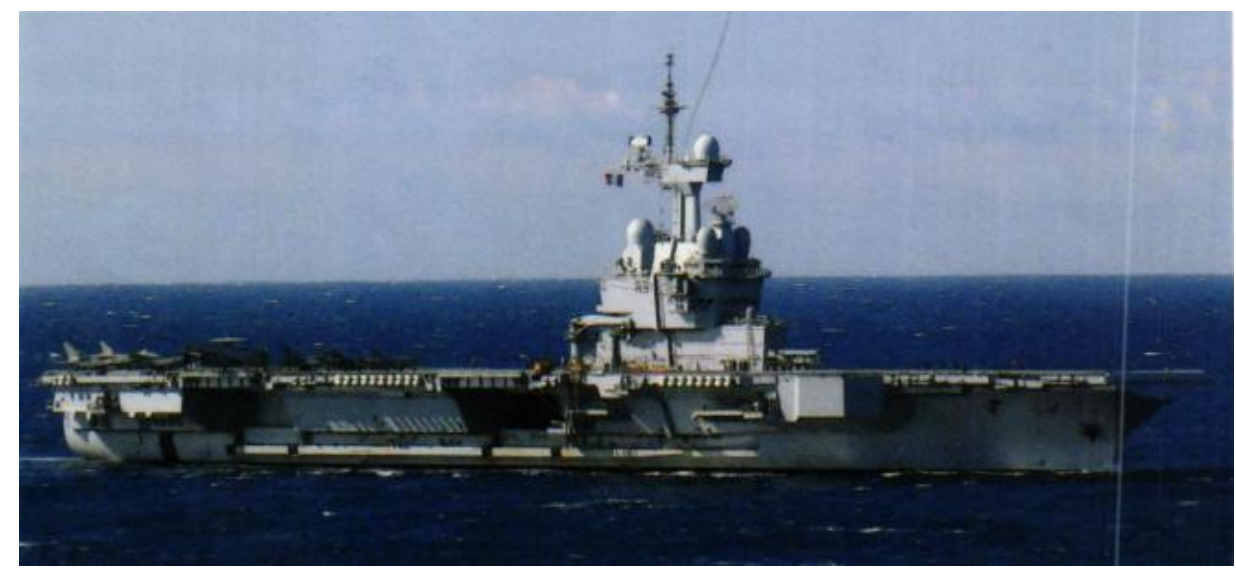

Figure 3 - Charles De Gaulle R91 (Source: Jane's Fighting Ships 2019-2020) 
The types of weapons owned by the Charles De Gaulle R91 Aircraft carrier are Missiles SAM EUROSAAM SAAM/F, 4 20F2 20mm Active Cannon, Decoy 4 CSEE Sagale AMBL-2A. Electronic Countermeasures ESM Thomson-CSF ARB 21 and EDM 2 ARBB 33B Jammers. In addition, it is also equipped with the Thales SMART-S Mk 2 Air Search Radar. Thomson-CSF DRBV 15C Sea Tiger Mk2 Air/Surface Search Radar. Combat Data System SENIT 8 Modernised, Links 11, 14, and 16, Syracuse 3 and FLEETSATCOM, Weapon Control System Thales control View. Electro-optic System 1 Safran PASEO NS Optronic Director.

d. Kuznetsov Class. The Russian State owns the Kuznetsov Class Aircraft carrier. The Aircraft carrier, named Admiral Kuznetsov 063, was launched on December 16, 1985. This Aircraft carrier has a flight deck for takeoff and landing with a length of 999 meters and a width of 229.7 meters. The Aircraft carrier Admiral Kuznetsov 063 has the capability to carry 16 Su-33 Flanker D or MIG-29K aircraft, 4 Su-25 UTG Frogfoots and 15 Ka-27 Helix or Ka$52 \mathrm{~K}$ Hokum B aircraft, $2 \mathrm{Ka}-31$ RLD Helix AEW. In addition, this Aircraft carrier is also capable of accommodating 2,586 personnel (200 officers, 626 aircrews) plus 40 flagstaffs.

The types of weapons owned by this Aircraft carrier are Missiles SSM 12 Chelomey SS-N-19 Shipwreck, 4 SAM Altair SA-N-9 Gauntlet, 8 SAM Altair CADS-N-1. Air/Surface Mortars 2 RBU-12000. Decoys: 10 PK 10 and 4 PK 2 Chaff Launcher. Electronic Counter Measures: ESM/ECM 8 Foot Ball, 4 Wine Flask (intercept), 4 Flat Track, 10 Ball Shield A and B. Also equipped with Radar Air Search Sky Watch. Radar Air/Surface Search Top Palte B. Radar Surface Search 2 Strut. Fire Control 4 Cross Sword (for SAM), IFF 4 Watch Guard. Weapon Control System 3 Tin Man Optronic Trackers.

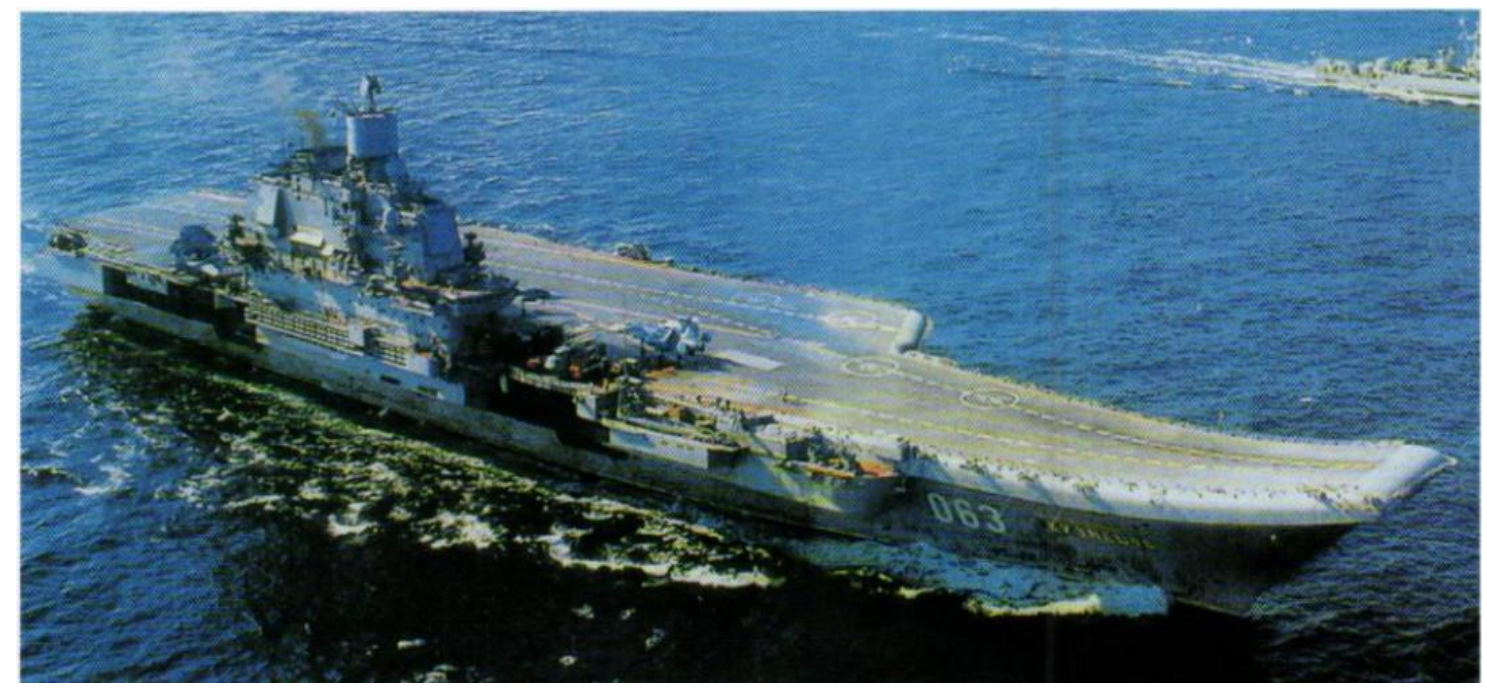

Figure 4 - Admiral Kuznetsov 063 (Source: Jane's Fighting Ships 2019-2020)

e. Lioning Class. The Liaoning Class air craft Aircraft carrier is owned by the State of China. China has two aircraft Aircraft carriers: Liaoning 16, which was launched on December 6, 1988, and Shandong 17, which was launched on April 26, 2017. This Aircraft carrier has a flight deck for takeoff and landing with a length of 999 meters and a width of 229.7 meters. The Aircraft carrier Liaoning 16 has the capability to carry more than $24 \mathrm{~J}-15$ aircraft and more than 12 helicopters. In addition, this Aircraft carrier can accommodate 1,960 personnel (200 officers, 626 aircrews) plus 40 flagstaffs.

The types of weapons owned by this Aircraft carrier are 3 Missiles SAM HHQ-10 18cell launchers, 3 type $113030 \mathrm{~mm}$ cannon, Air/Surface Mortars RPS Smerch-2 system, 2 RBU-6000 12-barrel launchers, 4 Decoys type 726 chaff launchers. It is also equipped with Radar Air Search type 381B Top Plate. 


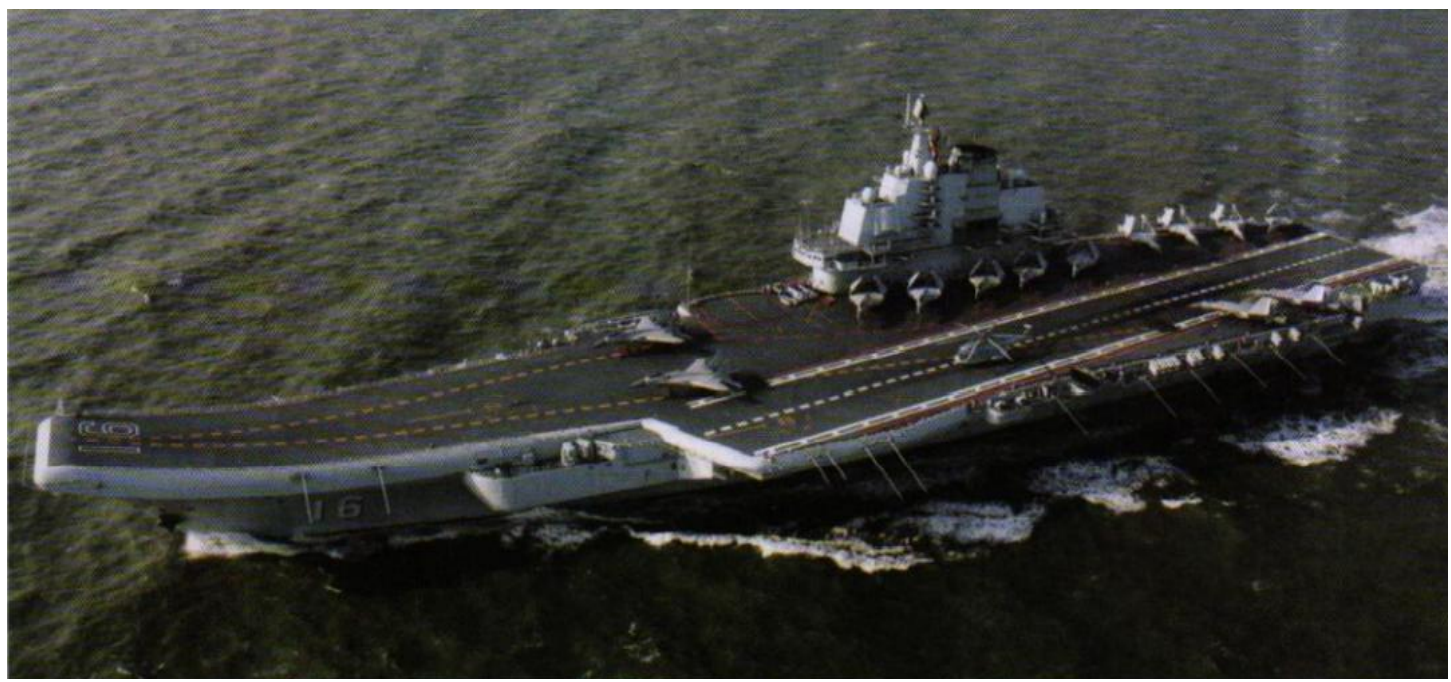

Figure 5 - Liaoning 16 (Source: Jane's Fighting Ships 2019-2020)

f. Cavour Class. The Cavour Class Aircraft carrier is owned by the Italian State. The Aircraft carrier, named Cavour C550, was launched on July 20, 2004. This Aircraft carrier has a flight deck for takeoff and landing with a length of 721.8 meters and a width of 111.5 meters. The Cavour C550 Aircraft carrier has the capability to carry as many as 8 AV-8B Harrier II or JSF aircraft and more than 12 helicopters. In addition, this Aircraft carrier is also capable of accommodating 654 personnel (203 air groups) plus 140 flagstaff and 325 troops.

The types of weapons owned by this Aircraft carrier are 4 Missiles SAM DCNS Sylver Octuple VLS. 2 Oto Melara Super Rapid Strales 76 mm/62 cannon. 2 Decoys Breda SCLAR$\mathrm{H}$ 20-barrel trainable chaff/decoy launchers. Electronic Counter Measures ESM/ECM MM/SLQ-750. In addition, it is also equipped with the SPS 798 Long Range Air Search Radar (RAN-40L), Selex EMPAR G-band Air Search, and Missile Guidance Radar. Combat Data System Horizon Derivative Flag and Command Support System. Weapon Control System Galileo Avionica SASS Optronic Director, 2 Selex NA-25XP.

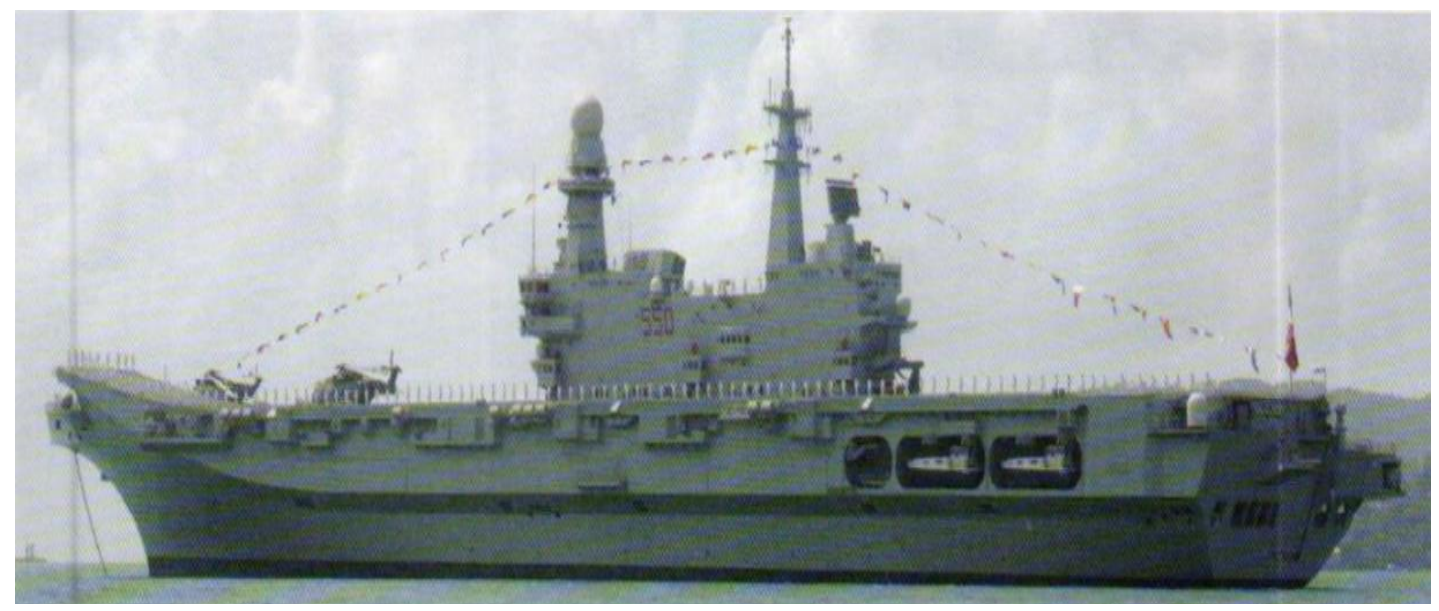

Figure 6 - Cavour C550 (Source: Jane's Fighting Ships 2019-2020)

In order to realize the plan to build a Aircraft carrier by utilizing the islands of Natuna, Bitung, and Selaru, the Indonesian Navy needs to strengthen bases in those three areas, namely Ranai Naval Base, Naval Home Base VIII Manado, and Saumlaki Naval Base.

a. Ranai Naval Base. Naval Home Base IV Tanjung Pinang, which is under the ranks of $1^{\text {st }}$ Indonesian Fleet Command, oversees five Naval bases, namely: Ranai Naval Base, Batam Naval Base, Tanjung Balai Karimun Naval Base, Tarempa Naval Base and Dabo Singkep Naval Base. The most appropriate Naval Base to be developed among the five 
Naval Bases is Naval Base Ranai, located in the Natuna Islands. Ranai Naval Base has excellent potential to be developed into Naval Home Base. This is with the consideration that the development of this Naval Base also has the support of the local government because this area is very prone to conflicts and crimes as well as violations of territorial boundaries.

Geographically, Natuna is located at $3^{\circ}-4^{\circ} 46^{\prime}$ North Latitude (NL) and $107^{\circ} 45^{\prime}-108^{\circ}$ 23' East Longitude (EL) (Https://Travel.Detik.Com, 2021), which is in the north, close to the border areas of neighboring countries such as Malaysia, Singapore, Vietnam and Cambodia, and the South China Sea (Https://Dpmptsp.Natunakab.Go.ld, 2021) . The biggest threat in Natuna currently arises from outside, namely China, which unilaterally recognizes that the South China Sea is their territory. This unilateral recognition by China is based on a map made by China itself so that the Natuna Islands region became part of China's power. China uses the Nine Imaginary Lines or Nine-Dash Lines, namely the demarcation line formed by the Chinese government in 1949, to control most of the South China Sea.

These situations and conditions can lead to the possibility of conflict, namely in the form of Chinese military aggression in Natuna, which is very likely to occur. Therefore, Indonesia must prepare the best strategy to deal with this possibility because it will be difficult for Indonesia to match China's sea power in a short time if a conflict occurs. The developer of Ranai Naval Base to become Naval Home Base in order to support the construction of Aircraft carriers in the region is a strategic step to increase national power of deterrence and defense at the South China Sea border.

Apart from China, there are also fishing vessels from several countries such as the Philippines, Thailand, and Vietnam, which often violate Indonesia's maritime boundaries. As a result of illegal fishing, the state's losses per year can reach up to Rp 240 trillion, according to calculations from the Ministry of Maritime Affairs and Fisheries (Kurnia, 2017). Another threat is smuggling, such as narcotics and illegal fuel transfer (illegal mining). Meanwhile, the military threat that should be watched out for is the violation of maritime, air, and land boundaries (Prakoso, 2017).

Another factor that supports Natuna as a Aircraft carrier is the availability of airbase facilities, namely the Raden Sadjad airbase in Natuna (Https:/Www.Bing.Com, 2021). Airbases are indispensable as a spot to take off fighter planes which are alerted as one element of the strength of the Aircraft carrier. Thus, it is very fitting if Ranai Naval Base is developed into Naval Home Base to support the development of a Aircraft carrier in Natuna.

b. Naval Home Base VIII Manado. Naval Home Base VIII Manado is under the ranks of $2^{\text {nd }}$ Indonesian Fleet Command, in charge of four Naval Bases, namely: Melonguane Naval Base, Toli-Toli Naval Base, Gorontalo Naval Base, and Bau-bau Naval Base. However, Bitung and the four Naval Bases are further compared to Bitung and Naval Home Base VIII Manado's distance so that the most appropriate to be developed as a Aircraft carrier here is Naval Home Base VIII Manado. The selection of Naval Home Base VIII Manado as the Aircraft carrier took into account various factors, including the availability of facilities and infrastructure, the availability of airbase facilities, and the availability of human resources (HR). In addition, Naval Home Base VIII Manado is already the Main Base, so the organizational structure has been formed, it only needs to be added to the Aircraft carrier Unit as a special unit for its development.

Manado is the capital city of North Sulawesi province. It is the second-largest city in Sulawesi after Makassar, geographically located at $1^{\circ} 30^{\prime}-1^{\circ} 40^{\prime}$ North Latitude and $124^{\circ} 40^{\prime}$ $124^{\circ} 50^{\prime}$ East Longitude in the north close to the border with the Philippines. Threats that occur in the sea border area of North Sulawesi are the duty and responsibility of Naval Home Base VIII Manado to overcome them.

The number of transnational crimes that occur in this region is quite extensive. This province has places for the movement of people and goods on an international scale. Among them are Sam Ratulangi Airport in Manado and Bitung Harbor. Cases of law violations that often occur around the border and involve citizens of other countries are narcotics crimes and fisheries crimes. In addition, there are also potential vulnerabilities for other international crimes, such as arms trafficking, human trafficking, and terrorism. The vulnerability of terrorism crimes in this region results from the situation and conditions that occur in the 
Philippines, especially in the Southern Philippines. This area is a base for the activities of the militant group led by Abu Sayyaf. There are armed groups called the Moro National Liberation Front (MNLF) and the Moro Islamic Liberation Front (MILF) in the Balut-Sarangani area. Therefore, this region has become an area prone to armed conflicts and acts of terror for years (Prakoso, 2017).

The hijacking incident that had occurred in this area was done by the Abu Sayyaf group, who took 12 crew members of the KM Brahma ship hostage, three of whom were crew members from North Sulawesi. Therefore, Mr. Olly Dondokambey, while serving as the Governor of North Sulawesi, has reminded sailors who will cross the sea bordering Indonesia with the Philippines to be alert to pirate attacks in the sea area (Https://Www.Beritasatu.Com, 2021).

The factors that support Naval Home Base VIII Manado to be developed into a Aircraft carrier are considerable. Naval Home Base VIII Manado already has more complete facilities and infrastructure because of its status as the Main Base. The development of Naval Home Base VIII Manado considers that Manado has Sam Ratulangi International Airport, which is about $37 \mathrm{~km}$ from Bitung City using the Manado-Bitung main road if you travel by car only takes about one and a half hours. In addition, it is also close to Bitung Harbor Pier, namely: Samudera Pier (607 m long); Nusantara Pier (504 m long); Industri Kimia Dasar Pier/IKD (148 m long); Landing Craft Tank/LCT Pier (20 m long) and Local Pier (60 m long) (Http://Pidii.Info, 2020).

c. Saumlaki Naval Base. Naval Home Base IX Ambon is under the ranks of $3^{\text {rd }}$ Indonesian Fleet Command, overseeing four Naval Bases: Aru Naval Base, Tual Naval Base, Saumlaki Naval Base and Ternate Naval Base. Of the four Naval Bases, the most suitable to support the construction of Aircraft carriers is the Saumlaki Naval Base, located in the Tanimbar Islands. Saumlaki Naval Base can be developed into Naval Home Base to carry out functions such as Naval Home Base VIII Manado, with the addition of a Aircraft carrier Unit as a unit that is specific to the base.

Saumlaki is located in the West Southeast Maluku Regency, $\pm 500 \mathrm{~km}$ to the south of Ambon City. Geographically, Saumlaki is located at $6^{\circ}-8^{\circ} 30^{\prime}$ South Latitude and $125045^{\prime}$ $133^{\circ}$ East Longitude (Lusnarnera, 2018). Saumlaki also has a strategic position because it is located close to the border between Indonesia and Australianera, precisely from the northern part of Australia.

In Saumlaki, the most significant potential threat comes from Australia because it is located in the south of Indonesia. Australia is one of the NATO member countries with support from the United States in the defense sector. US Marines strengthened the country of Australia in Darwin in mid-May 2015. The US has made Darwin a major military base and has drastically increased its military operations in western and northern Australia. America argued that this was done to balance China's power and as an effort to secure American interests in the region. In fact, the distance between Darwin and Selaru Island, East Nusa Tenggara is only 473 kilometers and can be reached in less than 20 minutes using an F-16 Fighting Falcon fighter. Meanwhile, the distance between Darwin and the Masela Block, which contains fossil energy, is only 492 kilometers (Nurmantyo, 2016).

Another thing to note is that the Australian government has published a defense white paper entitled "Defending Australia in the Asia-Pacific Century: Force 2030". The Australian Defense Minister believes that the Royal Australian Navy will grow into a bigger and stronger maritime power, supported by its increasing capabilities (Marsetio, 2014).

The developments that occur in the defense force of Australia can be a potential threat to Indonesia, which is located in the north of Australia. This is because Australia has many interests which require them to cross through the territory of Indonesia.

The factor that supports Saumlaki can be developed to support the construction of Aircraft carriers is the availability of facilities that can be used as an airbase, namely Mathilda Batlayeri Airport. The location of this airport is Jalan Mangkawar, Lorulun. The airport has a runway length of $1,641 \mathrm{~m} \times 30 \mathrm{~m}$ (Http://Www.Mtbkab.Go.ld, 2021). Mathilda Batlayeri Airport can be used as a takeoff area for warplanes that are alerted as one element of the strength of the Aircraft carrier. 


\section{CONCLUSION AND RECOMMENDATIONS}

In order to support the government's plan to build an aircraft Aircraft carrier using the islands of Natuna, Bitung, and Selaru, the Indonesian Navy needs to strengthen its bases in these three areas by developing Ranai Naval Base, Naval Home Base VIII Manado, and Saumlaki Naval Base. It is necessary to add a Aircraft carrier unit equipped with equipment and weapons systems with the sophisticated technology in developing the three bases like detection equipment such as air search radars and air and surface search radars, as well as weapons systems such as anti-air missiles, rockets, and cannons that can repel air attacks. In addition, it also needs to be equipped with electronic warfare equipment and weapons, such as Electronic Support Measure (ESM), Electronic Counter Measure (ECM), and Electronic Counter Counter Measure (ECCM) equipment. The development of Aircraft carriers in the three regions will increase the country's power of deterrence and defense at sea.

In its implementation, in order that the strengthening of the Indonesian Naval Base as a Aircraft carrier at the frontier to increase the power of deterrence and national defense at sea can be carried out properly, a further study is needed at the leadership level of the Indonesian Navy, Indonesian National Armed Forces, government, and related officials so that it can be adapted to the needs and developments of the strategic environment, both at the national, regional and global levels. This is intended so that the strengthening of the Indonesian Naval Base as a Aircraft carrier has the value of long-term continuity for the future.

\section{REFERENCES}

1. Aan Kurnia, Between Threats and Opportunities (Jakarta: Epicentrum Walk, 2017), hlm.13.

2. Aan Kurnia, Between Threats and Opportunities, 2017, hlm.96.

3. Aan Kurnia, Between Threats and Opportunities, 2017, hlm.6.

4. Ade Supandi, "Pembangunan Kekuatan TNI AL Dalam Rangka Mendukung Visi Indonesia Sebagai Poros Maritim Dunia" Jurnal Pertahanan Agustus 2015, volume 5, Nomor 2.

5. Alex Pape, Jane's Fighting Ships 2019-2020 (IHS Markit, 2020).

6. Departemen Pendidikan Nasional, Kamus Besar Bahasa Indonesia Pusat Bahasa, Edisi 4 (Jakarta: PT. Gramedia Pustaka Utama, 2008).

7. Gatot Nurmantyo, Berjuang Dan Bergotong Royong Mewujudkan Indonesia Sebagai Bangsa Pemenang (Jakarta: Mabes TNI, 2016).

8. "Https://Katadata.Co.Id/Berita/2017/12/14/Tiga-Pulau-Disulap-Jadi-Kapal-Induk-Tni-Ba kal-Beroperasi-2019," Diakses Kamis 1 April 2021, Pkl. 13.28 WIB.

9. "Https://Travel.Detik.Com/Detiktravel/d-5123101/Kondisi-Geografis-Pulau-Natuna-Berdasarkan-Peta-Lengkap-Dengan-Iklimnya," Diakses Selasa, 20 April 2021, Pkl.02.21 WIB.

10. "Https://Dpmptsp.Natunakab.Go.Id/Profil-Kabupaten-Natuna/\#: :Text=Secara\%20Geo grafis\%2C\%20wilayah\%20Kabupaten\%20Natuna,Selatan\%20berbatasan\%20dengan\%2 OKabupaten\%20Bintan\%2C," Diakses Selasa, 20 April 2021, Pkl.01.44 WIB.

11. "Https:/Nww.Bing.Com/Search?Q=Dari+17.504+Pulau+di+Indonesia\%2C+16.056+ te lah+diverifikasi+PBB+\%7C+merdeka.Com\&cvid=b5399429ebfe4f4f992ea918c316887d\& aqs=edge...69i57.1468j0j1\&pglt=43\&FORM=ANNTA1\&PC=ASTS," Diakses Selasa, 4 Mei 2021, Pkl. 09.58 WIB.

12. "Https:/Nww.Beritasatu.Com/Nasional/357581/Perlu-Kewaspadaan-Di-Laut-Perbatasan-Filipina-Manado," Diakses Rabu, 5 Mei 2021, Pkl. 11.44 WIB.

13. "Http://Pidii.Info/Index.Php?Option=com_k2\&view=itemlist\&layout=category\&task= tegory\&id=139\&Itemid=221," Diakses Rabu, 5 Mei 2020, Pkl. 11.42 WIB.

14. "Http://Www.Mtbkab.Go.Id/Bandar-Udara," Diakses Jumat, 21 Mei 2021, Pkl. 11.56 WIB.

15. Ibid., hlm.41. 
16. Ibid.

17. I Nengah Putra, "Analisis Ancaman Maritim Sebagai Dampak Perkembangan Lingkungan Strategis" Bintang Surabaya, 2016, hlm. 3.

18. I Made Wirartha, Metodologi Penelitian Sosial Ekonomi (Yogyakarta: C.V. Andi Offset, 2006), 155.

19. Karel Fredrik Gaus Basar Lusnarnera, "Perumusan Rencana Strategik Manajemen Bandara Saumlaki Maluku Tenggara Barat Periode 2014 - 2018," Universitas Atma Jaya, 2014.

20. Lukman Yudho Prakoso, "Strategi Pertahanan Dalam Penanganan Kejahatan Lintas Negara Di Perbatasan Laut Manado Sulawesi Utara Tahun 2017.

21. Lukman Yudho Prakoso, "Strategi Pertahanan Dalam Penanganan Kejahatan Lintas Negara Di Perbatasan Laut Manado Sulawesi Utara Tahun 2017."

22. Mabesal, "Keputusan Kasal Nomor Kep/1771/XI.2013 Tentang Buku Petunjuk Administrasi Standarisasi Pangkalan TNI Angkatan Laut" (Jakarta, 2013).

23. Marsetio, Paradikma Baru TNI Angkatan Laut Kelas Dunia (Jakarta: Mabesal, 2014), hlm.13.

24. Marsetio, "Strategi TNI Angkatan Laut Dalam Pengamanan Batas Maritim NKRI," Universitas Diponegoro, 2014, Volume 17.

25. Muhammad Zulkifli, "The Development Strategy of Navy Base as A Carrier in The Order of Improving The State Defense at Sea," RJOAS, 2021

26. Muhammad Zulkifli, "Determining The First Priority Of The First Arsenal Location To Support The Operation Of The Indonesian Warship In Safety Of The East Indonesian Sea Region With Ahp Methods," International Journal of ASRO, Number 2, pp.42-53, Volume 10 (2019).

27. Muhammad Zulkifli, "The Development Strategy of Navy Base as A Carrier in The Order of Improving The State Defense at Sea."

28. Prasetya, Eko. 2021. "Dari 17.504 Pulau di Indonesia, 16.056 telah diverifikasi PBB". https://www.merdeka.com/peristiwa/dari-17504-pulau-di-indonesia-16056-telahdiverifikasi-pbb.html. Diakses pada tanggal 4 Mei 2021, pukul 09.58 WIB

29. Rajab Ritonga, Kesadaran Baru Maritim Biografi Laksamana TNI Dr. Marsetio (Jakarta: PT. Gramedia Pustaka Utama, 2016), hIm.119.

30. Till Geoffrey, Seapower - A Giude for The Twenty First Century, Edisi 2 (London, 2009), hlm.345.

31. "Undang-Undang Nomor 34 Tahun 2004 Tentang TNI" (Lembaran Negara Republik Indonesia Tahun 2004 Nomor 127, n.d.). 